\title{
논문 4
}

[2012-09-RP-004]

\section{국내외 신재생에너지 기술 경쟁력 분석 - 태양광·연료전지를 중심으로 -}

구기관*, 이덕기, 홍종철, 박수억**

\section{An Analysis of the Competitiveness of Renewalble Energy Technologies \\ Kikwan Koo*, Deokki Lee, Jongchul Hong and Soouk Park**}

Abstract In this study, we studied solar cell and fuel cell. To estimate the technology competitiveness, we used patent analysis using patent information and delphi method. For patent analysis, PII indicating the impact of patent was used. Also to analysis PIl, citations data of registered and published patent were used from 2001 through 2010 in the United States, Japan, South Korea and the European Patent Office. And the delphi method results of the 'International trend analysis on the Green Energy Technology and the establishment of international cooperation models(2009)' were cited to estimate the technology level. According to the analysis results, Korea's patent registration growth rate was fairly high, but the patent impact and technology levels were significantly lower than in the United States, Japan and Germany. Especially in the solar cell, United States's PII is 1.8, but Korea's PII is 0.2. And the technology level of United States is 7 to 8 , but Korea's is 5 to 6 .

Therefore, to improve technology competitiveness, Korea need to enhance the core technology R\&D, and set up the consumer-oriented $R \& D$ strategy for commercialization from $R \& D$ planning phase.

In this study, we analysed competitiveness of renewable energy which is not actively discussed. But there are limitations of the study because we used the result of past research and patent data in the past 10 years. Therefore to accurate research the period of patent data should be extended. Finally diverse indicators for measuring the technology competitiveness should be researched and developed.

Key words

Renewable energy(신재생에너지), Technology(기술), Competitiveness(경쟁력), Solarcell(태양전지), Fuelcell(연료전지),

Patent analysis(특허분석), Delphi method(델파이 방법)

(접수일 2012. 7. 18, 수정일 2012. 8. 17, 게재확정일 2012. 9. 6)

* 한국에너지기술연구원 (R\&D Strategy Center, Korea Institute of Energy Research)

E-mail : kkkoo@kier.re.kr Tel : (042)860-3171 — Fax : (042)860-3097

** 한국에너지기술연구원 (R\&D Strategy Center, Korea Institute of Energy Research)

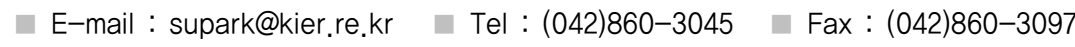




\section{Subscript}

PII : patent impact index
$C P P \quad:$ cites per patent
CII $:$ current impact index
PFS : patent family size
CIGS : copper, indium, gallium, selenide
PEMFC : proton exchange membrane fuel cell
$M C F C:$ molten carbonate fuel cell
SOFC : solid oxide fuel cell

\section{1. 서 론}

최근 화석연료 고갈, 기후변화, 원전 안전성 문제 등으로 신재생에너지에 대한 관심이 세계적으로 고조되고 있다. 신 재생에너지는 무한하고 깨끗한 에너지자원을 활용하여 인간 이 필요로 하는 에너지를 제공하기 때문에 그 중요성이 날로 높아지고 있으며, 점차 신재생에너지 시장 규모가 증가하고 있다. 이에 따라 주요 선진국을 비롯한 세계 각국은 급성장하 는 신재생에너지시장을 선점하기 위해 많은 노력과 재원을 투입하고 있다. 비단 선진국뿐만 아니라, 중국, 인도, 브라질 등 개발도상국도 신재생에너지 기술개발 경쟁에 적극적으로 뛰어들고 있다.

우리나라도 저탄소 녹색성장이라는 국가비전아래 세계 시 장 선점을 위하여 신재생에너지분야에 많은 자원을 투입하고 있다. 앞으로 이러한 경쟁환경은 점점 더 심화될 것으로 예상 된다.

따라서, 이러한 경쟁환경을 극복해 나가기 위해서는 국내 신재생에너지기술의 경쟁력을 파악하는 것이 필요하다.

기술 경쟁력 측정은 대체적으로 관련 전문가에게 직접 설 문조사하여 파악하는 방법과 R\&D지표(연구개발비, 연구인 력, 특허, 논문 등)를 도출하여 파악하는 방법이 있다. ${ }^{(6)}$

박현우(2007)는 PMP의 기술 경쟁력 측정을 위하여 특허 인용점유율과 특허점유율을 활용하였다. 특허 인용점유율은 특허의 질적수준을 보여주는 지표로 전체의 인용횟수에서 국 가별로 차지하는 비율을 의미한다. ${ }^{(7)}$ 정하교(2007)는 특허건 수를 활용한 현시기술우위지수(RTA: Revealed Technological
Advantage)와 특허의 피인용정보를 활용한 현재영향지수 (CII: Current Impact Index)를 활용하여 기술 경쟁력을 측 정·비교하였다. 현재영향지수(CII)는 특정주체의 과거 5년 동 안의 기술혁신 성과가 현재 시점(연도)에 미치고 있는 기술적 영향력을 나타내는 지수로서, 과거 5 개년 특허의 피인용 건 수를 활용한다. ${ }^{(10)}$

이밖에도 특허의 질적수준을 평가하기 위한 방법으로 특허 당 피인용수(CPP: Cites per Patent), 특허영향지수(PII)가 활용되고 있다. ${ }^{(12)}$ 특허청(2004)에서는 NT분야의 기술 경쟁 력 측정을 위한 지표로 특허건수, 시장확보지수(PFS: Patent Family Size)와 함께 특허영향지수(PII: Patent Impact Index)를 활용하였다. ${ }^{(11)}$

본 논문에서도 신재생에너지분야의 기술 경쟁력을 분석하 기 위하여 특허정보를 활용하였다. 특허정보는 기술혁신을 측정하기 위한 지표로서 중요한 관심의 대상이 되고 있다. 이 미 항공기반산업, 휴대용멀티미디어단말기(PMP)분야 등 다 양한 분야에서 연구동향 및 기술 경쟁력분석을 위해 활용되 었으나, 신재생에너지분야에서는 특허를 활용한 기술 경쟁력 연구는 미미한 상황이다. 보다 정확한 분석을 위하여 현재영 향지수(CII)가 아닌 특허영향지수(PII)를 활용하였다.

델파이방법은 많은 연구에서 기술수준을 평가하기 위해 사 용되어져 왔다. 전문가 설문을 통하여 기술수준을 측정하는 것으로 전문가의 주관이 반영될 수 있는 단점이 있다. 본 논 문에서는 델파이 방법과 특허분석을 함께 활용하여 태양전지 와 연료전지에 대한 기술 경쟁력을 측정하고자 하며, 이를 통 하여 R\&D 전략 수립을 위한 시사점을 제공하고자 한다.

\section{2. 분석 방법 및 대상}

앞서 밝힌 바와 같이 본 논문은 태양광과 연료전지분야를 대상으로 특허분석과 델파이 방법을 활용하여 기술 경쟁력을 측정하였다. 특히 델파이 방법은 지난 연구결과를 활용하였 으며, 특허분석의 경우 델파이 연구결과를 발전시키고자 동 일조건의 기술분류와 기술여건, 동일한 측정대상(동일 국가) 을 활용하여 분석을 수행함으로써 델파이 방법과 함께 기술 경쟁력을 분석하였다. 


\section{논문 4}

\section{1 특허영향지수(PII)}

노이즈를 제거한 특허데이터의 피인용 정보를 기반으로 특 허영향지수(PII)를 기술 경쟁력 측정에 활용하였다. 특허영 향지수는 특허당 피인용지수(CPP)와 달리 해당 기술분야의 특성과 다른 경쟁주체의 기술수준이 고려되어 상대적인 정량 적 지표를 제공한다. ${ }^{(12)}$

$$
P I I=\frac{C P P a}{C P P t}
$$

$C P P_{a}$ : 특정주체의 특허당 평균 피인용 수

$C P P_{t}$ : 해당분야 전체 특허의 평균 피인용 수

특허분석 대상은 미국, 일본, 한국, 유럽에 등록 및 공개된 특허를 대상으로 하였으며, 특허의 특성상 출원된 이후 1년 에서 2 년 동안의 심사기간 또는 비공개 기간이 소요되기 때 문에 정확한 분석을 위하여 2001년부터 2010년까지를 검색 기간으로 설정하였다. 특허분석을 활용한 연구의 경우 일반 적으로 연구시점을 기준으로 1년에서 2년 전 데이터를 유효 데이터로 활용하고 있다.

검색 범위는 Title, Abstract, Claim으로 키워드 검색을 통하여 특허검색을 실시하였으며, 특허데이터베이스는 Thomson Innovation을 사용하였다.

분석 대상은 태양전지와 연료전지 기술에 관한 특허로서 델파이 방법과 동일한 기술분류를 활용하였다. 분석대상은 다음과 같다.

Table 1. 분석대상 기술

\begin{tabular}{c|c|c}
\hline 대분류 & 태양전지 & 연료전지 \\
\hline \multirow{3}{*}{ 중분류 } & $\begin{array}{c}\text { 결정질실리콘, } \\
\text { 실리콘박막, } \\
\text { CIGS, } \\
\end{array}$ & PEMFC, \\
& $\begin{array}{c}\text { 염료감응, } \\
\text { 유기 }\end{array}$ & MCFC, \\
& SOFC \\
\hline
\end{tabular}

특허검색을 통하여 추출된 특허 중 '태양전지를 활용한 양 식업'등 기술 경쟁력 측정과 직접적으로 관련이 없는 특허는

1) PII 값이 1 이상인 경우 상대적으로 특허의 질적 수준이 높음을 의미 한다.
분석대상 특허에서 제외하였다. 노이즈를 제거한 유효 특허 데이터는 다음과 같다.

Table 2. 유효 특허데이터

\begin{tabular}{c|c|c}
\hline 기술명 & 태양전지 & 연료전지 \\
\hline & 미국: 5,106 & 미국: 4,559 \\
검색 국가 & 일본: 3,316 & 일본: 3,419 \\
& 유럽: 1,486 & 유럽: 1,507 \\
& 한국: 2,011 & 한국: 916 \\
\hline
\end{tabular}

유효 특허데이터의 피인용 정보를 활용하여 분석대상 기술 별로 각 국가의 PII지수 결과값을 산출하였다. 주요국의 PII 값은 다음과 같다.

Table 3. 국가별 PII 결과값(태양광)

\begin{tabular}{c|c|c|c|c|c}
\hline 구분 & 미국 & 일본 & 독일 & 대만 & 한국 \\
\hline $\begin{array}{c}\text { 결정질 } \\
\text { 실리콘 }\end{array}$ & 2.21 & 0.54 & 0.56 & 1.62 & 0.19 \\
\hline $\begin{array}{c}\text { 실리콘 } \\
\text { 박막 }\end{array}$ & 1.55 & 0.97 & 0.90 & 1.30 & 0.24 \\
\hline CIGS & 1.86 & 0.64 & 0.46 & 0.09 & 0.16 \\
\hline $\begin{array}{c}\text { 염료 } \\
\text { 감응 }\end{array}$ & 1.42 & 0.77 & 0.33 & 0.26 & 0.26 \\
\hline 유기 & 2.16 & 0.67 & 0.73 & 0.43 & 0.28 \\
\hline
\end{tabular}

Table 4. 국가별 PII 결과값(연료전지)

\begin{tabular}{c|c|c|c|c}
\hline 구분 & 미국 & 일본 & 독일 & 한국 \\
\hline PEMFC & 1.37 & 0.69 & 0.78 & 0.28 \\
\hline MCFC & 1.95 & 0.04 & 0.07 & 0.03 \\
\hline SOFC & 2.29 & 0.31 & 0.37 & 0.11 \\
\hline
\end{tabular}

\subsection{Delphi 방법}

기술수준 조사는 각 기술별 주요 특허등록국가를 대상으로 전문가 델파이 방법을 통해 기술 수준 조사 평가한 '그린에너 지기술 국제동향 분석 및 국제협력 모델 구축(2009)' 연구결과 를 활용하였다. 본 연구 결과에서 활용한 기술수준 측정지표는 미국 NASA에서 적용하는 기술수준 단계인 TRL(Technology Readiness Level)을 적용하였으며, 설문 대상은 산업계와 대 학 및 정부출연 연구 전문가들로 구성되었다. 
Table 5. 설문 응답 현황

\begin{tabular}{c|c|c}
\hline 기술명 & 태양전지 & 연료전지 \\
\hline 설문 대상(명) & 13 & 7 \\
\hline 응답(건) & 6 & 4 \\
\hline 회신율(\%) & 46.2 & 57.1 \\
\hline
\end{tabular}

TRL은 크게 research, development, business로 구분되 며, 1단계 기초이론부터 9 단계 실제시스템 증명(상용화)로 구성되어 있다.

\section{Table 6. TRL 기술수준 체계}

\begin{tabular}{c|c}
\hline 단계 & 기술수준 \\
\hline 1 & 기초이론 \\
\hline 2 & 개념정립 \\
\hline 3 & 기술특성 분석 \\
\hline 4 & 요소기술 타당성 조사 \\
\hline 5 & 시제품제작/현장모의 실험 \\
\hline 6 & 시스템/하부시스템 구현 \\
\hline 7 & 실제 시제품 구현 및 현장 실험 \\
\hline 8 & 실제 시스템 완벽 구현 \\
\hline 9 & 실제 시스템 증명(상용화) \\
\hline
\end{tabular}

전문가 델파이 조사를 통하여 도출된 주요국가의 기술수준 결과값은 다음과 같다.

Table 7. 국가별 기술수준(태양광)

\begin{tabular}{c|c|c|c|c|c}
\hline 구분 & 미국 & 일본 & 독일 & 대만 & 한국 \\
\hline $\begin{array}{c}\text { 결정질 } \\
\text { 실리콘 }\end{array}$ & 9 & 9 & 9 & 9 & 9 \\
\hline $\begin{array}{c}\text { 실리콘 } \\
\text { 박막 }\end{array}$ & 8 & 9 & 8 & 7 & 6 \\
\hline CIGS & 9 & 9 & 8 & 4 & 5 \\
\hline $\begin{array}{c}\text { 염료 } \\
\text { 감응 }\end{array}$ & 6 & 9 & 8 & 5 & 6 \\
\hline 유기 & 9 & 9 & 8 & - & 5 \\
\hline
\end{tabular}

Table 8. 국가별 기술수준(연료전지)

\begin{tabular}{c|c|c|c|c|c}
\hline 구분 & 미국 & 일본 & 독일 & 캐나다 & 한국 \\
\hline PEMFC & 9 & 9 & 8 & 8 & 7 \\
\hline MCFC & 9 & 8 & 9 & 9 & 6 \\
\hline SOFC & 8 & 8 & 8 & - & 4 \\
\hline
\end{tabular}

\section{3. 기술 경쟁력}

앞서 밝힌 바와 같이 특허분석을 통한 특허영향지수와 델 파이 방법을 통한 기술수준을 활용하여 국가별 기술 경쟁력 을 살펴보았다.

기술의 질적 수준에 관련한 특허분석과 전문가 델파이 방 법에 의한 기술수준 평가를 활용하여 보다 신뢰성있는 기술 경쟁력 평가결과를 제시하고자 한다. 그림에서 $\mathrm{X}$ 축은 정성적 평가(전문가 델파이) 결과 값이며, $\mathrm{Y}$ 축은 정량적 평가(특허 영향지수) 결과 값을 나타낸다.

우선 태양전지부터 살펴보면, 1 세대인 결정질실리콘태양 전지는 이미 일반화된 기술로 기술수준에서는 큰 차이가 없 었으나, 기술 영향력에서는 다소 차이가 있는 것으로 분석되 었다.

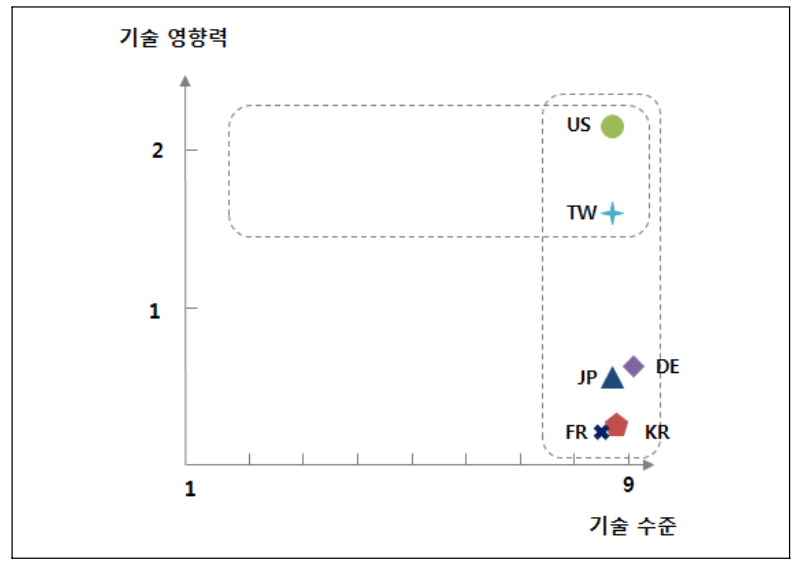

Fig. 1 실리콘태양전지 기술 경쟁력

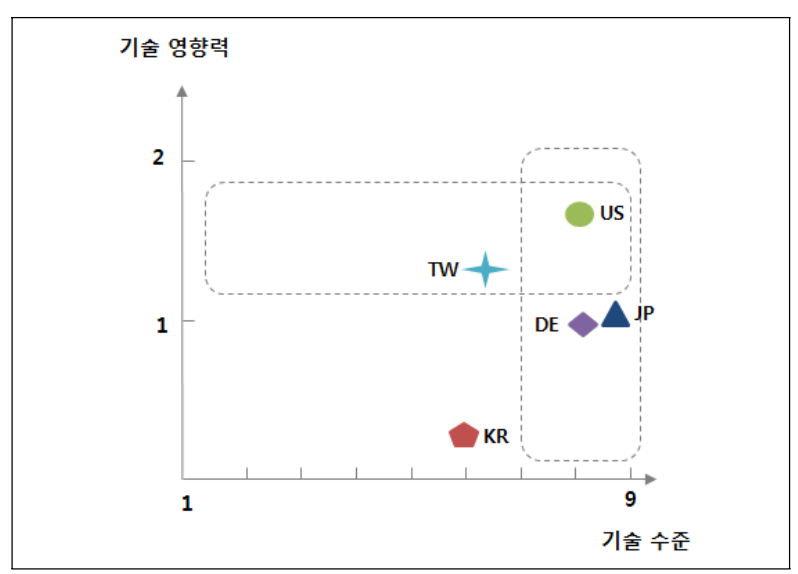

Fig. 2 실리콘박막태양전지 기술 경쟁력 


\section{논문 4}

하지만 실리콘박막, CIGS, 염료감응 등 차세대 태양전지 기술은 미국, 일본 등 주요 선진국에 비해 기술 경쟁력이 상 당히 뒤쳐지고 있는 것으로 분석되었다.

실리콘기반의 결정질실리콘태양전지와 실리콘박막태양전 지의 경우, 한국의 기술 영향력은 0.19 와 0.24 로 낮았으나 대 만의 경우 1.62 와 1.30 으로 일본이나 독일보다 높은 기술 영 향력을 나타내었다. 미국은 결정질실리콘태양전지 2.21, 실 리콘박막태양전지 1.55 로 해당 기술분야의 기술개발에 가장 많은 영향을 미치고 있는 것으로 분석되었다.

반면 기술수준은 9 단계로 국가간에 큰 격차가 존재하지는 않는 것으로 분석되었다.

결정질실리콘태양전지는 이미 상용화가 상당부분 이루어진 분 야로 기술경쟁력 확보를 위해서는 원천기술 확보보다는 비용절 감, 시스템 효율 향상 등에 중점을 둔 기술개발 전략이 요구된다.

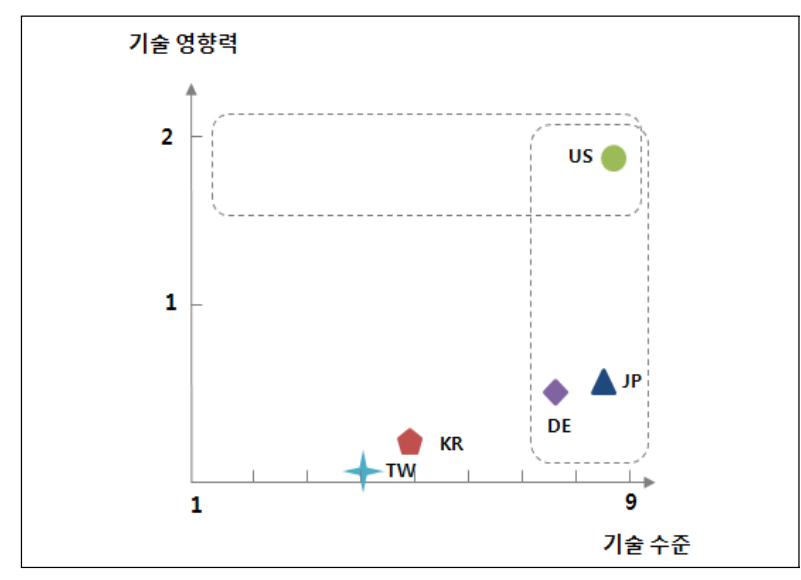

Fig. 3 CIGS박막태양전지 기술 경쟁력

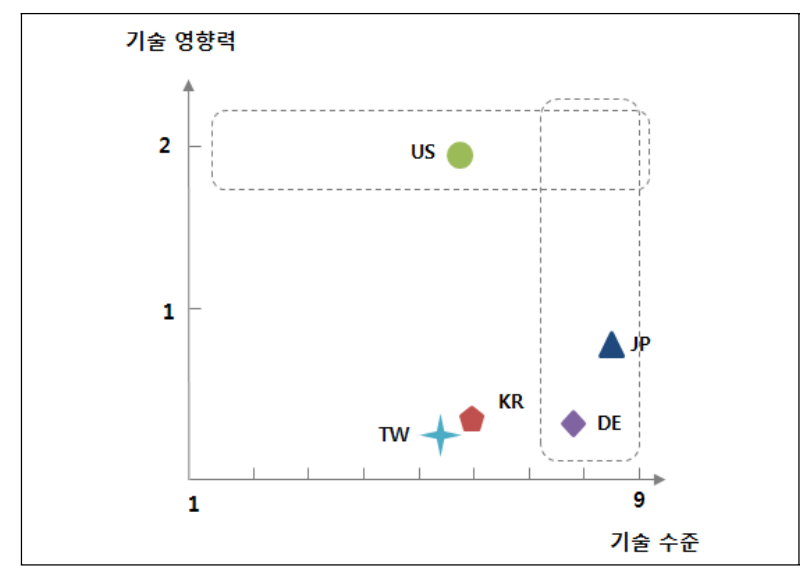

Fig. 4 염료감응태양전지 기술 경쟁력
CIGS박막태양전지분야는 미국은 기술 영향력 1.86 , 기술 수준 9 로 가장 높은 기술 경쟁력을 가지고 있는 것으로 분석 되었다. 독일과 일본은 기술 영향력이 0.46과 0.64로 다소 일본이 높은 것으로 분석되었으며, 기술수준도 일본 9 단계, 독일 8단계로 다소 일본이 높은 것으로 분석되었다. 반면 한 국은 독일과 일본에 비해 기술수준은 낮으나, 대만보다는 다 소 높은 것으로 분석되었다. 특히 한국의 CIGS 기술수준은 5 단계로서 시제품 제작 및 현장 모의실험 수준인 것으로 나 타났다. 한편 대만은 기술 영향력 0.09, 기술수준 4단계로 결 정질실리콘태양전지에 비해 기술수준과 기술영향력이 상당 히 낮은 것으로 보아 CIGS태양전지분야에서는 기술경쟁력을 확보하지 못한 것으로 분석되었다.

반면 염료감응태양전지의 경우, 기술영향력은 미국(1.42), 일본(0.77), 독일(0.33), 한국(0.26), 대만(0.26) 순으로 분석

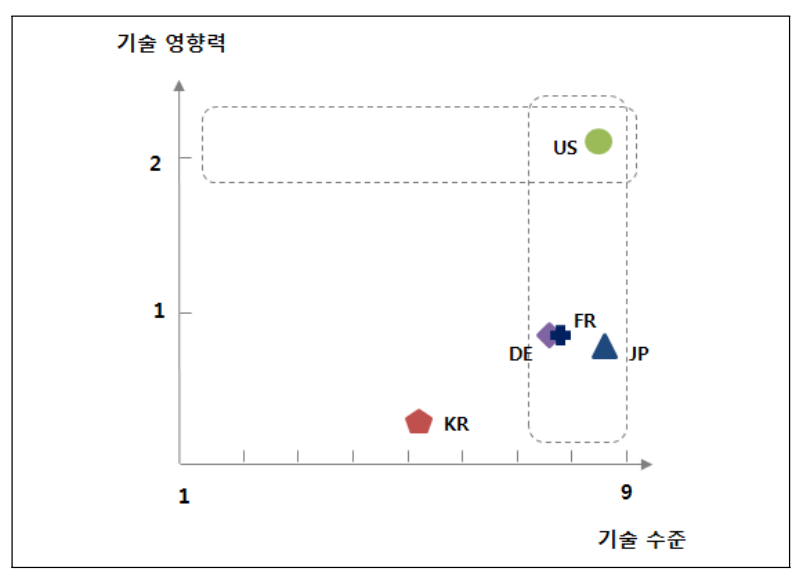

Fig. 5 유기태양전지 기술 경쟁력

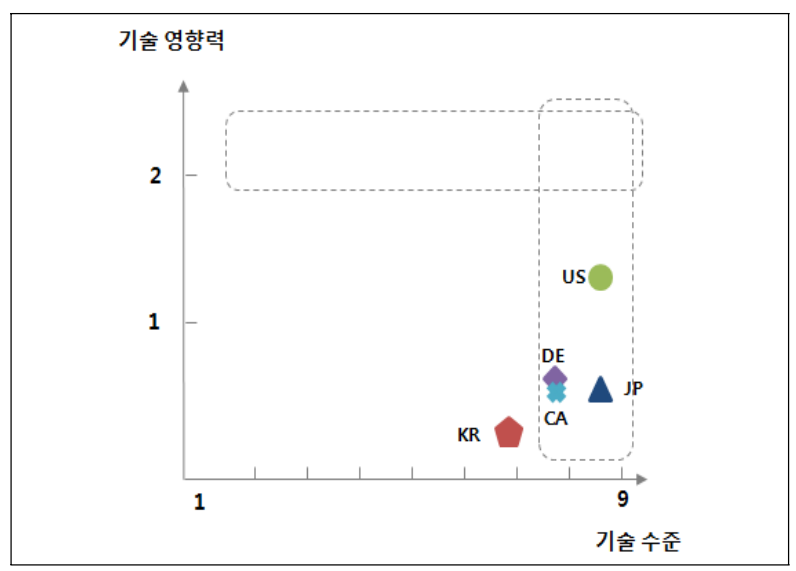

Fig. 6 PEMFC 기술 경쟁력 
되었으며, 기술수준은 일본(9), 독일(8), 미국(6), 한국(6), 대만(5)로 조사되어 미국과 한국의 기술수준에 큰 격차는 없 으나, 일본이 상당히 앞서고 있는 것으로 분석되었다.

유기태양전지분야는 미국이 가장 높은 기술 경쟁력을 확보 하고 있으며 일본, 독일, 프랑스가 그 뒤를 잇고 있는 것으로 분석되었다. 기술 영향력의 경우 미국(2.05) 다음으로 프랑 스(0.79), 독일(0.77), 일본(0.67), 한국(0.27) 순으로 분석 되었으며, 기술수준은 미국 9단계, 일본 9단계, 독일 8단계, 프랑스 8단계, 한국 5 단계로 조사되었다.

반면, 대만은 유기태양전지분에서는 아직 활발한 연구개발 이 이루어지지 않고 있는 것으로 조사되었다.

연료전지분야를 살펴보면, $\mathrm{PEMFC}$ 의 경우 미국, 일본, 독 일, 캐나다 등 주요 국가간에 비슷한 기술경쟁력을 확보하고 있는 것으로 분석되었으며, 한국도 주요 선진국과 큰 차이를

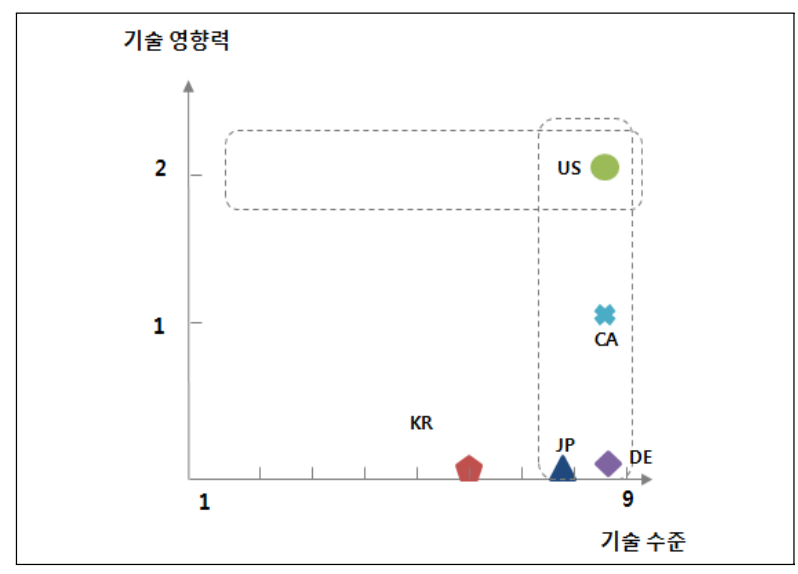

Fig. 7 MCFC 기술 경쟁력

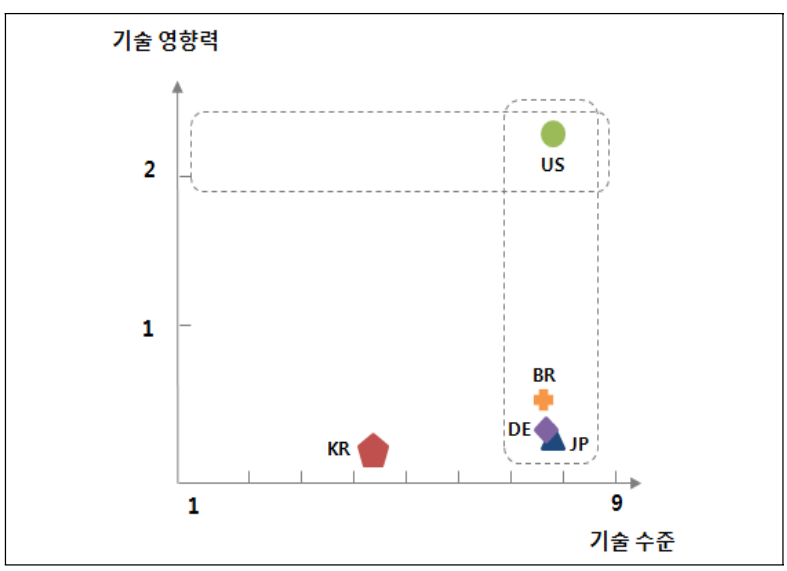

Fig. 8 SOFC 기술 경쟁력
보이지 않은 것으로 분석되었다.

반면 $\mathrm{MCFC}$ 와 $\mathrm{SOFC}$ 는 국가간 기술경쟁력이 다소 차이가 있는 것으로 나타났다. $\mathrm{MCFC}$ 는 미국, 캐나다, 일본, 독일 간 에 기술수준에서 큰 차이는 없으나 기술 영향력에서 미국과 캐나다의 영향력이 가장 높은 것으로 보아 이 두 국가가 핵심 연료전지 기술을 확보하고 있는 것으로 분석되었다.

기술별로 자세히 살펴보면, $\mathrm{PEMFC}$ 분야의 경우 미국과 일 본이 9 단계(상용화)로 가장 높은 기술수준을 보유하고 있으 며, 다음으로 독일과 캐나다(8단계), 한국(7단계) 순인 것으 로 조사되었다. 기술 영향력은 미국이 1.37 로 가장 높은 영향 력을 나타냈으며, 독일 0.78 , 일본 0.69 , 한국 0.28 로 한국의 기술 경쟁력이 아직은 낮은 것으로 분석되었다. 하지만 다른 연료전지분야에 비하여 미국, 캐나다 등 주요 국가들과 격차 가 크지 않은 것으로 분석되었다.

$\mathrm{MCFC}$ 의 경우 미국 1.95 , 캐나다 1.02 로 높은 기술 영향력 을 보인 반면에 한국(0.03)과 일본(0.04), 독일(0.07)은 비슷 한 영향력을 나타내었다. 하지만 기술수준에서는 주요 국가 들이 8 9단계인 반면 한국은 6단계(시스템/하부 시스템 구 현)로 기술수준이 낮은 것으로 조사되었다.

하지만 미국과 일본은 연도별 특허등록 건수 감소하거나 정 체하고 있으나, 국내는 오히려 다소 증가하고 있는 것으로 나 타났다. 기술개발활동의 증가에 따른 특허등록이 증가하고 있 는 만큼 국내의 기술 경쟁력이 점차 높아질 것으로 예상된다. $\mathrm{SOFC}$ 의 경우 일본, 독일, 영국의 기술수준은 8단계(시스템 완벽 구현)로 높으나, 기술 영향력은 일본 0.31 , 독일 0.37 , 영국 0.50으로 주요 핵심기술을 확보하고 있는 미국(2.29)과 상당한 기술 영향력 차이가 존재하는 것으로 분석되었다.

한국의 기술수준은 4 단계이며, 기술 영향력은 0.11 로 독 일, 일본, 영국과는 기술 영향력은 큰 차이를 보이지 않으나, 기술수준에서 상당한 격차가 있는 것으로 분석되었다. 따라 서 기술 경쟁력을 높이기 위해서는 응용기술보다는 핵심기술 이나 원천기술에 집중할 필요가 있다.

\section{4. 결 론}

태양광과 연료전지분야에서 국내의 기술개발활동도 최근 들어 뚜렷하게 증가하고 있는 양상이다. 그만큼 예전에 비해 신재생에너지분야에 많은 재원을 투입하고 있다. 하지만 기술 
경쟁력을 측정한 결과, 현재는 기술개발에 따른 경쟁력 향상 효과가 뚜렷하지 않은 상황이다. 이미 상용화가 이루어진 일 부기술을 제외하면 우리나라의 기술경쟁력은 매우 낮은 것으 로 분석되었다.

태양광의 경우, 2000 년대 중반부터 기술개발활동이 급증하 였으며, 특히 결정질실리콘태양전지와 실리콘박막태양전지 를 중심으로 기술개발이 이루어져 왔다. 하지만 결정질실리콘 태양전지를 제외하면 주요 기술개발 국가들에 비해 기술수준 이 상당히 뒤쳐져 있는 것으로 분석되었다.

한편 연료전지분야는 $\mathrm{SOFC}$ 를 중심으로 기술개발중이며, $\mathrm{MCFC}$ 관련 기술개발은 정체상태인 것으로 나타났다. 이러한 기술개발 추이를 볼 때, $\mathrm{SOFC}$ 가 연료전지 보급을 위한 중추적 인 역할을 담당할 것으로 판단된다. 기술 경쟁력 측면에서 미 국이 기술수준과 기술 영향력 모두 가장 높은 것으로 분석되었 다. 반면 한국은 독일, 일본 등과 비슷한 기술 영향력을 확보하 고 있으나, $\mathrm{SOFC}$ 의 기술수준은 여전히 상당한 격차가 존재하 는 것으로 분석되었다.

기술경쟁력 확보를 위해서는 기술 성숙도, 핵심기술 확보 가능성 등을 고려하여 각 기술별 경쟁력 확보 전략이 요구된 다. 특히 기술 영향력과 기술수준 향상을 위해서는 상용화 전 략이 필요하다. 즉, 특허나 논문 생산을 위한 기술개발이 아닌 $R \& D$ 기획단계에서부터 산업계와 협력을 통하여 정확한 기술 수요 파악, 명확한 기술 상용화 목표와 전략 설정이 요구된다. 이러한 의미에서 R\&D 전과정에서 기술 수요자 등 다양한 계 층이 참여하는 오픈이노베이션이 확대될 필요가 있다.

또한 국가 연구개발 과제의 경우 대부분 3년 이상의 중장기 과제이다. 과제 수행기간 동안 대내외 환경 또는 산업계 요구 기술의 변화가 충분히 일어날 수 있기 때문에 과제수행기간 동안 이러한 변화를 반영할 수 있는 정책적 제도 마련이 요구된다.

본 논문에서는 특허분석과 델파이 방법을 활용하여 태양광 과 연료전지분야의 기술 경쟁력을 측정하고자 하였다. 특허분 석에 활용한 데이터는 2001년 2010년 사이에 등록 및 공개 된 특허로 검색 대상기간을 확대하여 분석할 필요성이 있다. 따라서 본 논문은 최근 10 년간의 개발된 기술의 현시점 기술 경쟁력이라는 한계점이 존재한다.

또한 좀더 명확한 비교를 위해서는 각 지표들을 수치화하여 기술 경쟁력 점수를 제시할 필요성이 있다. 하지만 본 논문에 서는 2 가지 지표를 통한 포지셔닝만을 보여줌으로서 기술 경
쟁력 비교에 한계점을 가지고 있다. 따라서 향후 기술 경쟁력 측정을 위한 다양한 지표들을 연구하고, 이러한 지표들의 수 치화를 통하여 국가별 기술 경쟁력 점수를 제시할 필요성이 있다.

향후 기술 경쟁력 측정을 위한 지표로서 PII지수뿐만 아니 라 시장확보지수, 과학연계지수, 특허 점유율 등 다양한 특허 분석 방법론들이 활용될 필요가 있다.

에너지기술분야의 기술 경쟁력 측정을 위한 첫 발걸음인 만 큼 향후 해당분야의 활발한 연구를 기대해 본다.

\section{References}

[1] 박주형, 김완두, 2006, "국내 기계산업의 산업/기술경쟁력 분석 및 시사점”, 대한기계학회 춘추학술대회논문집, 대한기 계학회, pp. 20-25.

[2] 박현우, 김기일, 2007, “특허정보를 통한 PMP 연구동향과 기술경쟁력 분석”, 한국콘텐츠학회논문지, 한국콘텐츠학회, 제7권, 제9호, pp. 117-126.

[3] 박수억 외, 2009, “그린에너지 국제동향 분석 및 국제협력 모 델 구축”, 한국에너지기술연구원, pp. 73-125.

[4] 에너지자원기술평가원, 2009, “그린에너지기술개발 전략 로 드맵”, 지식경제부.

[5] 정하교, 황규승, 2008, “특허정보를 활용한 항공기반산업의 기술경쟁력 분석”, 경영과학, 한국경영과학회, 제25권, 제2호, pp. 111-127.

[6] 특허청, 2004, “NT 특허분석 보고서”, 특허청.

[7] 한국특허정보원, 2005, "기술로드맵 작성을 위한 특허분석방 법론”, 산업자원부.

[8] 홍미영, 황기하, 홍정석, 이경재, 2011, “중점 녹색기술 기술 수준 현황과 시사점”, KISTEP issue paper 2011-18.

[9] Daisuke Kanama et al., 2007, “Analysis of Japan's nanotechnology Competitiveness”, Science \& Technology trend, Quarterly review No. 25, pp. 33-49.

[10] D. Harhoff et al., 1999, Citation frequency and the value of patented inventions.

[11] Hong, K. D. 1992, "Stability Improvement of Center Lathes”, J. of KSPE, Vo1. 2, No. 2, pp. 123-126.

[12] REN21, 2011, "Renewables 2010 : Global status report", Renewable Energy Policy Network for the 21th centry.

[13] Shilpa Govada et al., 2008, Patent Analysis of RFID Technology.

[14] www.thomsoninnovation.com 


\section{구 기 관}

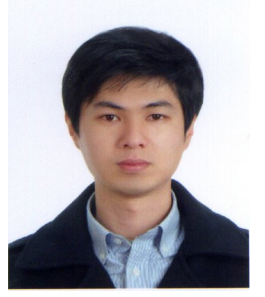

2008년 충주대학교 산업경영공학과 공학사

2011년 인하대학교 경영학과 석사

현재 한국에너지기술연구원 위촉연구원

(E-mail : kkkoo@kier.re.kr)

\section{홍 종 철}

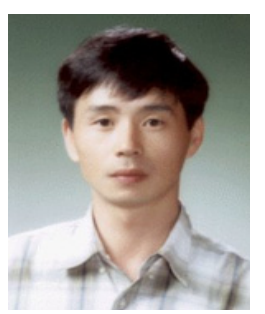

2009년 한국산업기술대학교

지식기반기술에너지대학원 박사

현재 한국에너지기술연구원 책임기술원

(E-mail : jchong@kier.re.kr)

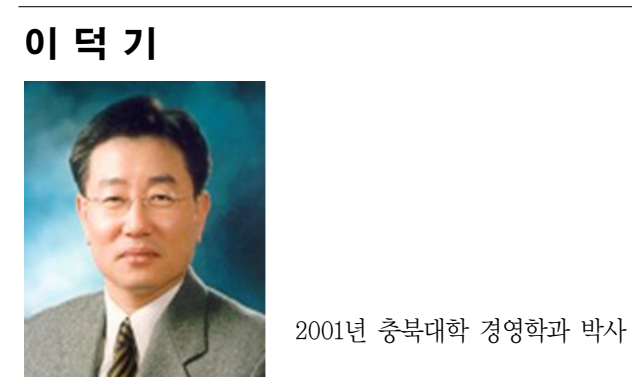

현재 한국에너지기술연구원 책임기술원

(E-mail : deokki@kier.re.kr)

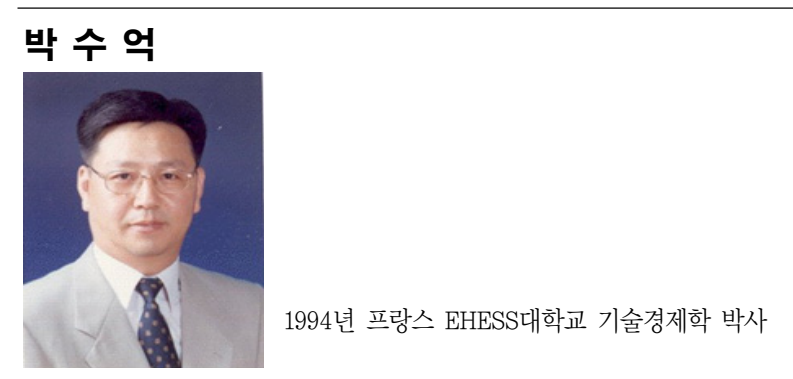

현재한국에너지기술연구원 책임기술원

(E-mail : supark@kier.re.kr) 